\title{
125. Identification of Proteins Specific to Friend Strain of Spleen Focus forming Virus (SFFV)
}

\author{
By Yoji Ikawa,*) Mitsuaki Yoshida, *) and Hiroshi YoshiKurA**) \\ (Communicated by Toshio KuroKawa, M. J. A., Dec. 12, 1978)
}

Introduction. The Friend leukemia virus (FLV) induces rapid neoplastic proliferation of erythroid precursor cells in susceptible mice. ${ }^{1)}$ The FLV complex contains two distinct virus components, ${ }^{2)-4)}$ spleen focus forming virus (SFFV), which is replication-defective and responsible for transformation of its target erythroid precursor cells, and replication-competent helper virus, inducing lymphoid leukemia after a long lalent period. Nucleic acid hybridization studies indicated that genomic RNA of SFFV contained a set of SFFV-specific sequences and sequences homologous to helper MuLV.5,)6) Therefore, SFFV-specific sequences may code for protein(s), which are responsible for transformation of erythroid precursor cells as the src gene of Rous sarcoma virus codes for the specific protein, which is responsible for transformation of mesenchymal cells. ${ }^{7}$ ) Previously a glycoprotein of M.W. 55,000 was observed in several Friend erythroid leukemia lines. ${ }^{8)}$

The isolation of nonproducer cells infected with SFFV ${ }^{9,10), 12)}$ or of those cells producing large excess of SFFV over helper MuLV ${ }^{6}$ ) has made it possible to analyze the protein products coded by the SFFV genome. As such cells contained a large amount of SFFV RNA, we can expect to detect SFFV-coded proteins, if the RNA is ever translated.

This paper describes briefly the identification of M.W. 55,000 and 120,000 dalton proteins as SFFV-specific proteins, the former crossreacting with anti-Rauscher murine leukemia virus (MuLV) gp70 serum, and was abundant in such an excess SFFV-producing or a nonproducing SFFV-infected erythroleukemia clone.

Materials and methods. T3-K-1 cells, also called as K-1, a subclone of Friend leukemia cell line, T3-C1-2,11) released a large excess of SFFV over helper $\mathrm{MuLV} .^{6)}$ The helper component was isolated free from SFFV by repeated limiting dilutions of the T3-K-1 virus in SC-1 cells. FVTCT, a nonproducer Balb/c mouse cells infected with SFFV, was isolated and donated by Fieldsteel $e t$ al. and has been

*) Department of Viral Oncology, Cancer Institute, Tokyo.

**) Department of Genetics, Institute of Medical Science, University of Tokyo. 
maintained in our laboratory ${ }^{12)}$ and SFFV-NRK C1-1 cells, another nonproducer rat cells were isolated by Troxler et al.9) Monospecific goat antisera to Rauscher p12 and gp70 were generously supplied by Dr. T. August (John Hopkins University), and goat anti-serum to Rauscher MuLV p30 was supplied by Resources and Logistics, Virus Cancer Program, National Cancer Institute, U.S.A. under the U.S.Japan Cooperative Research Program. Goat anti-sera to the whole Molony MuLV virions was a gift from Dr. O. N. Witte, M.I.T.

The infected cells were labeled with $\left[{ }^{35} \mathrm{~S}\right]$ methionine as described previously, ${ }^{13)}$ and immunoprecipitation of viral proteins was carried out according to the method of Kessler. ${ }^{14)}$

Results and discussion. The viral proteins in Friend leukemia cell line, T3-K-1, were studied by immunoprecipitation with antisera to the virion components. Cells were labeled with $\left[{ }^{35} \mathrm{~S}\right]$ methionine and the radioactive immunoprecipitates from the extracts were analyzed by polyacrylamide gel electrophoresis and autoradiography. As shown in Fig. 1 (track A2) and summarized in Table I, goat antiserum to p30 precipitated proteins with molecular weight of 65,000 and 30,000 daltons. The latter small protein was identified as a mature virion protein, p30. The $65 \mathrm{~K}$ protein was also precipitated with anti p12 but not with anti gp70 (Fig. 1, A3, A4), suggesting $65 \mathrm{~K}$ as precursor polypeptides for gag proteins of helper MuLV. Actually, 65K protein was also present in SC-1 cells infected only with helper MuLV, which had been isolated from T3-K-1 virus and had been confirmed free from SFFV (Fig. 1, B2, B3), and was consistent with the reported molecular size of gag gene-coded precursor containing p15, p12, p30 and p10 sequences. $^{15)}$

From the same extract of T3-K-1 cells, a unique protein of $55 \mathrm{~K}$ daltons was precipitated by antiserum to gp70 together with small amount of $85 \mathrm{~K}, 70 \mathrm{~K}$ and $17 \mathrm{~K}$ proteins (Fig. 1, A4). In SC-1 cells infected with T3-K-1 helper MuLV, three intense bands corresponding to $85 \mathrm{~K}, 70 \mathrm{~K}$ and $17 \mathrm{~K}$ daltons were found with anti-gp70 (Fig. 1, B4). This immunospecificity and molecular weight suggested that $70 \mathrm{~K}$ protein was gp70, a glycosylated env gene product, $17 \mathrm{~K}$ is $15 \mathrm{E}$ or $12 \mathrm{E}$, and $85 \mathrm{~K}$ is probably uncleaved precursor (gp85 ${ }^{\text {env }}$ ) of gy70.16) Thus these three faint bands of $80 \mathrm{~K}, 70 \mathrm{~K}$ and $17 \mathrm{~K}$ (Fig. 1,A4) are shown to be coded by env gene of helper MuLV genome in T3-K-1 cells. Since the $55 \mathrm{~K}$ protein was not detected even in trace amount in helper $\mathrm{MuLV}$-infected cells, the protein of $55 \mathrm{~K}$ seemed to be specific to and coded by the SFFV genome, rather than the degradation product of gp.70. Since this $55 \mathrm{~K}$ protein was precipitable with anti-gp70, its glycosylation profile was preliminarily studied by autoradiography after $\left[{ }^{14} \mathrm{C}\right]$-glucosamine labelling, confirming its glycoprotein nature 


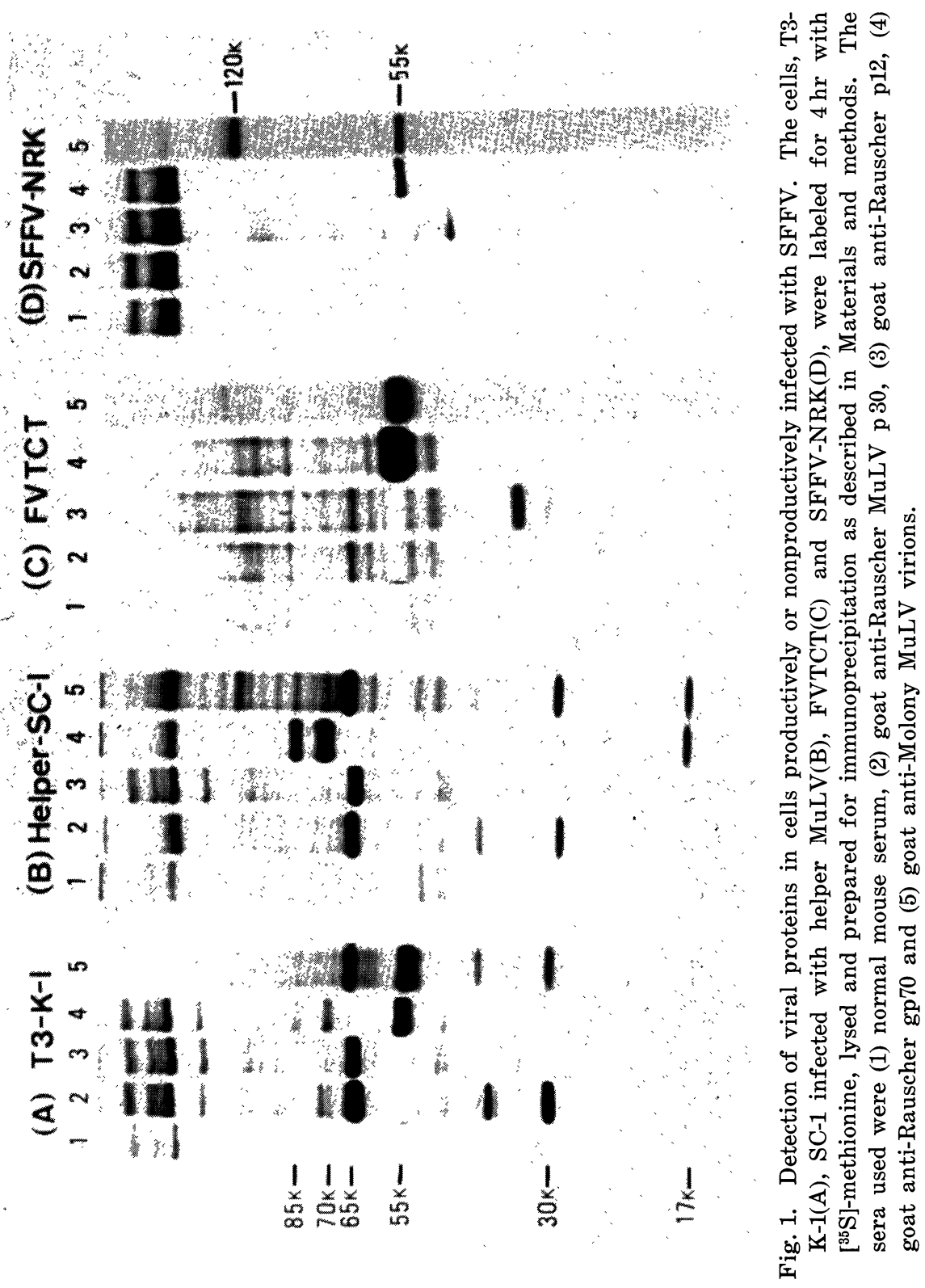


Table I. Viral antigen expression in cells infected with SFFV

\begin{tabular}{|c|c|c|c|c|c|}
\hline \multirow{2}{*}{ Cells } & \multirow{2}{*}{$\begin{array}{l}\text { Viral genome } \\
\text { in the cells }\end{array}$} & \multicolumn{4}{|c|}{$\begin{array}{l}\text { Proteins }{ }^{\dagger} \text { precipitated } \\
\text { with antisera to }\end{array}$} \\
\hline & & gp70 & p12 & p30 & Mo-MuLV \\
\hline \multicolumn{6}{|l|}{ Producer cells } \\
\hline T3-K-1 & $\begin{array}{l}\text { SFFV and } \\
\text { Helper }\end{array}$ & $\begin{array}{c}(85 \mathrm{~K}) \\
(70 \mathrm{~K}) \\
55 \mathrm{~K} \\
(17 \mathrm{~K})\end{array}$ & $65 \mathrm{~K}$ & $\begin{array}{l}65 \mathrm{~K} \\
30 \mathrm{~K}\end{array}$ & $\begin{array}{l}65 \mathrm{~K} \\
55 \mathrm{~K} \\
30 \mathrm{~K}\end{array}$ \\
\hline $\begin{array}{l}\text { SC-1 } \\
\text { with MuLV }\end{array}$ & Helper & $\begin{array}{l}85 \mathrm{~K} \\
70 \mathrm{~K} \\
17 \mathrm{~K}\end{array}$ & $65 \mathrm{~K}$ & $\begin{array}{l}65 \mathrm{~K} \\
30 \mathrm{~K}\end{array}$ & $\begin{array}{c}(140 \mathrm{~K}) \\
(85 \mathrm{~K}) \\
65 \mathrm{~K} \\
30 \mathrm{~K}\end{array}$ \\
\hline $\begin{array}{l}\text { Nonproducer } \\
\text { FVTCT }\end{array}$ & SFFV & $55 \mathrm{~K}$ & $\begin{array}{l}\left(65 \mathrm{~K}^{*}\right) \\
(35 \mathrm{~K})\end{array}$ & $\left(65 \mathrm{~K}^{*}\right)$ & $\begin{array}{l}\left(65 \mathrm{~K}^{*}\right) \\
55 \mathrm{~K}\end{array}$ \\
\hline SFFV-NRK & SFFV & $55 \mathrm{~K}$ & $(120-130 \mathrm{~K})$ & - & $\begin{array}{l}120-130 \mathrm{~K} \\
55 \mathrm{~K}\end{array}$ \\
\hline
\end{tabular}

† The proteins are indicated by their molecular weight and protein in parentheses are detected only in small amounts. The $65 \mathrm{~K} *$ in FVTCT was slightly smaller than the normal Pr65gag band. NT: Not tested.

and difference from gp70 as shown by Racevskis et al. ${ }^{8)}$ (data not shown).

To confirm further the $55 \mathrm{~K}$ as SFFV-specific protein, nonproducer cells infected with SFFV were also analyzed similarly. A Friend leukemia cell line, FVTCT, showed a strong band of $55 \mathrm{~K}$ protein precipitable with anti-gp70 (Fig. 1, C4). This finding strongly indicated that the $55 \mathrm{~K}$ protein is specific to the SFFV genome. In much smaller amounts, however, we detected a band slightly smaller than Pr65 ${ }^{\mathrm{gag}}$, which was precipitated with anti-p12 and anti-p30 and a band of $35 \mathrm{~K}$ precipitated with anti-p12 (Fig. 1, C2, C3). These might be the products coded by partially expressed endogenous viral genes inducible from Balb/c mouse cells. In another nonproducer line, SFFV$\mathrm{NRK}$, the $55 \mathrm{~K}$ protein was again detected as a single component precipitable with anti-gp70 (Fig. 1, D2, D3, D4).

When goat antiserum to the whole virions of Molony strain of MuLV was used, a strong band of 120-130K daltons was detected in SFFV-NRK cells in addition to 55K protein (Fig. 1, D5). This 120$130 \mathrm{~K}$ protein was not precipitable from the same extract with antip30 or anti-gp70 (Fig. 1, D2, D4). Furthermore, helper MuLV-infected SC-1 cells showed no such $120-130 \mathrm{~K}$ protein precipitable with the same anti-serum to Molony MuLV (Fig. 1, B5). These results suggested that this protein might be an unknown polypeptide coded by the SFFV genome in SFFV-NRK cells. The similar $120 \mathrm{~K}$ protein was detected in the SFFV-infected cells by Housman and Witte (personal communication). This unique protein is very similar in their size to $100-120 \mathrm{~K}$ proteins coded by replication-defective viruses such 
as feline sarcoma virus, ${ }^{17)}$ avian MC 29 virus $^{18)}$ and Abelson leukemia virus. ${ }^{19)}$ However, in FVTCT, which is also a nonproducer SFFVinfected cell line, only a faint band of $120-130 \mathrm{~K}$ protein was found with the same antiserum to Molony MuLV (Fig. 1, C5). Furthermore, T3-K-1 cells which contained a large amount of $55 \mathrm{~K}$ protein did not show a strong band of 120-130K protein (Fig. 1, A5). This difference between SFFV-NRK and FVTCT or T3-K-1 cells might be explained by either of the followings: (a) Anti-Molony MuLV serum did not recognize the possibly existing $120-130 \mathrm{~K}$ protein in FVTCT or T3K-1 cells. (b) The protein of $120-130 \mathrm{~K}$ was rapidly degraded in mouse cells, but stayed longer in rat cells. (c) SFFV in FVTCT and T3-K-1 cells was different from SFFV in SFFV-NRK cells and did not code for $120-130 \mathrm{~K}$ protein.

Our findings that the main viral protein found in SFFV-infected cells was 55K, precipitable with anti-gp70, are not in good consistency with those by A. Bernstein et al. ${ }^{10)}$ and by M. Barbacid et al. ${ }^{20}$ ) Bernstein et al. ${ }^{10)}$ found only p15 in their mouse and rat nonproducer cells infected with SFFV and Barbacid et al. ${ }^{20)}$ identified only p15 and p12-related antigens in SFFV-NRK cells, but both groups did not detect any antigens which competed with gp70 in their radioimmunoassay. At present, we can not explain these contradictory findings between ours and theirs.

In conclusion, a protein of 55,000 daltons, precipitable with antigp70, was found in our hands in all the cells infected with SFFV but not in cells infected with helper MuLV, and a large amount of 120$130 \mathrm{~K}$ protein was detected in SFFV-NRK cells. These proteins are probably coded by the SFFV genome and one or both of them could be candidates for its transforming protein for its target erythroid precursor cells.

Acknowledgments. We thank Dr. Haruo Sugano for his discussion and encouragement during the work and also Miss Y. Hirayama and Miss M. Aida for their excellent technical assistance. This work was supported in part by Grant-in-Aid for Cancer Research from the Ministry of Education, Sciences and Culture, Japan and by a grant from the Princess Takamatsu Foundation for Cancer Research.

\section{References}

1) Friend, C.: J. Exp. Med., 105, 307 (1957).

2) Dawson, P. J., Tacke, R. B., and Fieldsteel, A. H.: Brit. J. Cancer, 22, 569 (1968).

3) Steeves, R. A., Eckner, R.-J., Bernnett, M., Mirand, E. A., and Trudel, P. J.: Natl. Cancer. Inst., 46, 1209 (1971).

4) Odaka, T.: Int. J. Cancer, 11, 567 (1973). 
5) Troxler, D. H., Boyars, J. K., Parks, W. P., and Scolnick, E. M.: J. Virol., 22, 361 (1977).

6) Ikawa, Y., and Yoshida, M.: Oncogenic Viruses and Host Cell Genes (eds. Ikawa, Y., and Odaka, T.). Academic Press Inc., New York (in press).

7) Brugg, J. S., and Erikson, R. L.: Nature, 269, 346 (1977).

8) Racevskis, J., and Koch, G.: J. Virol., 21, 328 (1977).

9) Troxler, D. H., Parks, W. P., Vass, W. C., and Scolnick, E. M.: Virology, 76, 602 (1977).

10) Bernstein, A., Mak, T. W., and Stephenson, J. R.: Cell, 12, 287 (1977).

11) Ikawa, Y., Aida, M., and Y. Inoue: Gann, 67, 767 (1976).

12) Fieldsteel, A. H., Kurahara, C., and Dawson, P.: Nature, 223, 1274 (1969).

13) Isaka, T., Yoshida, M., Owada, M., and Toyoshima, K.: Virology, 65, 226 (1975).

14) Kessler, S. W.: Immun., 115, 1617 (1975).

15) Barbacid, M., Stephenson, J. R., and Aaronson, S. A.: Nature, 262, 554 (1976).

16) Witte, O. N., and Baltimore, D.: J. Virol., 26, 750 (1978).

17) Khan, A. S., and Stephenson, J. R.: J. Virol., 23, 599 (1977).

18) Bister, K., Hayman, M. J., and Vogt, P. K.: Virology, 82, 431 (1977).

19) Witte, O. N., Resenberg, N., Paskind, M., Shields, A., and Baltimore, D.: Proc. Nat. Acad. Sci. U.S.A., 75, 2488 (1978).

20) Barbacid, M., Troxler, D. H., Scolnick, E. M., and Aaronson, S. A.: J. Virology, 27, 826 (1978). 